\title{
Management of Early Drought in Rice with Most Suitable Strains of Trichoderma harzianum
}

\author{
Ranvijay Singh $^{1 *}$, Ramji Singh $^{1 *}$, U.S. Singh ${ }^{2}$, Durga Prasad ${ }^{3}$ and Ajay Kumar ${ }^{4}$
}

${ }^{1}$ Department of Plant Pathology, Sardar Vallabhbhai Patel University of Agriculture and Technology, Modipuram, Meerut- 250110, UP, India ${ }^{2}$ International Rice Research Institute, India Office, 9th floor Agarwal Tower, Rajendra Place, New Delhi, India

${ }^{3}$ Department of Plant Pathology, College of Agriculture, BUAT Banda-210001, UP, India

${ }^{4}$ Department of Plant Pathology, Narendra Deva University of Agriculture and Technology, Kumarganj, Faizabad-224 229, UP, India

*Corresponding author

\section{A B S T R A C T}

\begin{tabular}{|l|}
\hline K e y w o r d s \\
Rice, Seed, Biopriming, \\
Drought, Efficacy, Stress
\end{tabular}

This experiment was conducted in pots, containing unsterilized soil under rain out shelter using rice variety IR-64. The rice seed were treated (bio-primed @ 10g/ Kg seed) with powder formulation of selected $T$. harzianum strains viz., IRRI-1, IRRI-2, IRRI-3, IRRI-4, IRRI-5, IRRI-6, TH-3, SVP-1 and SVP-3 before $24 \mathrm{hrs}$ of sowing. Root and shoot development were measured at 21 days after seed sowing in the rice crop season 2012 and 2013 by uprooting the rice plants. T. harzianum strains IRRI-6, IRRI-1 and IRRI-3 were found to support maximum root and shoot length in the rice plants, obtained from the seed treated with these strains. Remaining strains of $T$. harzianum i.e. IRRI-4, IRRI-2, SVP-1 IRRI-5 and SVP-3 were also able to support the enhancement of root and shoot length of rice plants at quite higher level, but comparatively little less than IRRI-6, IRRI-1 and IRRI-3.

\section{Introduction}

Rice (Oryza sativa L.), a member of family Gramineae and subfamily Oryzoidae, is the most important crop plant for human consumption, providing staple food for more than half of the world's population. Total global area under rice is about 165.00 million ha with total output of 496.6 million tones of paddy at an average yield of 3.01 tons $\mathrm{ha}^{-1}$ (FAO, 2016). Out of 2.7 billion rice consuming peoples, more than $95 \%$ live in Asia. About $90.0 \%$ of world's total rice is grown in Asian countries alone (FAO, 2016). India is the second largest producer and consumer of rice in the world after China. Rice is one of the most important food crops of India in terms of area, production and consumer preference. In India, rice provides food calories for more than two third populations. Indian share in global rice production has been 21.34 percent. In India, area under rice cultivation is $43.97 \mathrm{~m}$. ha with total output of $106.00 \mathrm{~m}$ tones with an average 
productivity of $2410 \mathrm{~kg} / \mathrm{ha}$ (Department of Agriculture and Cooperation Govt. of India, 2016). Rice is grown in almost all Indian states. Andhra Pradesh, Assam, Bihar, Karnataka, Madhya Pradesh, Maharashtra, Orissa, Punjab, Tamilnadu, Uttar Pradesh and West Bengal are major rice growing states and contribute a total of $92 \%$ of area and production of rice. Rice is a major crop in Uttar Pradesh and is grown in almost all districts with about $5.90 \mathrm{~m}$ ha area, which comprises $13.5 \%$ of total rice area in India. To meet the growing need of increasing population in the country and more so in the state of Uttar Pradesh, there is an urgent need to enhance rice productivity in the region. Efforts for enhancing the productivity have been limited by a number of biotic and abiotic stresses. Among the biotic stresses, fungi, bacteria, viruses, nematodes and phytoplasma causing diseases in rice plants are major one.

The abiotic stresses such as unfavorable temperature, drought, flood, chemicals (sodacity, salinity and mineral deficiency/excess, pollutants heavy metals/pesticides, gaseous toxins), mechanical injuries (wind, soil movement, submergence) are responsible for around $50 \%$ reduction in overall agricultural production (NIASM, 2016). In the world only $9 \%$ of the area is conducive for crop production, while $91 \%$ is under the influence of abiotic stress. This includes $25 \%$ under drought, $22 \%$ has got shallow depth, $22 \%$ is under mineral stress, $14 \%$ is under freezing stress and $11 \%$ is under water logged condition. Similarly in India also, $67 \%$ of the area is rainfed and crops in these areas invariably experience droughts of different magnitudes. Although in India, about $33 \%$ of the cropped area is under irrigation, but here also crop production is constrained by environmental stresses (NIASM, 2014). These biotic and abiotic stresses are considered as a serious constraint for rice production. Keeping in view the need of rice seed bio-priming with strains of $T$. harzianum is undertaken with objective: To study the efficacy of rice seed bio-priming with different strains of $T$. harzianum on root shoot development and drought stress.

\section{Materials and Methods}

The in vitro experiment was carried out on efficacy of rice seed bio-priming with different strains of $T$. harzianum on root shoot development and drought stress, using rice cultivar IR-64 which was sown in sandy loam soil on $10^{\text {th }}$ July in both crop seasons (20122014). Nine strains of Trichoderma harzianum were applied to the rice seed as seed bioprimming and seeds were shown in the pots with six replications in Completely Randomized Block Design (CRD). Pots containing rice plants raised from the seeds treated with $T$. harzianum were kept under the rain out shelter of the Department of Agriculture Biotechnology of Sardar Vallabhbhai Patel University of Agriculture and Technology, Meerut (U.P.), India. Seeds treated with plain water only served as untreated check. Thus the experiment consisted of 10 treatments (Table 1).

\section{Drought exposure at seedling stages}

Drought exposure to the rice seed lings were provided after 21 days of seed sowing under rainout shelter. Morpho- physiological observations were recorded on randomly selected three plants from each pot in each replication at seedling stage. These plants were uprooted and washed with tap water. The data were recorded on following parameters.

\section{Length and fresh weight measurement of root and shoot}

Root and shoot length were measured with the help of scale by selecting three plants randomly from each pot in each replication on 
the 21 day of germination. Average length was used for statistical analysis. Twenty one days old rice plant under control and stress (treated) were softly uprooted from pots. Root and shoot fresh weights were measured on electronic balance up to three decimal digits.

\section{Observations on leaf rolling}

Leaf rolling was recorded during drought period with following scale, (IRRI, 1996).

$0=$ Leaves healthy

1 = Leaves start to fold (shallow V - shape)

3 = Leaves folding (deep V - shape)

$5=$ Leaves fully cupped (U - shape)

$7=$ Leaves margins touching $(\mathrm{O}-$ shape $)$

$9=$ Leaves tightly rolled

Leaf rolling $(\%)=$

Sum of all wilting ratings

Total number of rating $\mathrm{X}$ maximum grade

\section{Results and Discussion}

The experiment was conducted in pots, containing unsterilized soil under rain out shelter using rice variety IR-64. The rice seed were treated (bio-primed @ 10g/ Kg seed) with powder formulation of selected $T$. harzianum strains viz., IRRI-1, IRRI-2, IRRI3, IRRI-4, IRRI-5, IRRI-6, TH-3, SVP-1 and SVP-3 before $24 \mathrm{hrs}$ of sowing. Root and shoot development were measured at 21 days after seed sowing in the rice crop season 2012 and 2013 by uprooting the rice plants. The data have been presented in Table 1, 2, 3 and 4.

\section{Root and shoot length}

The maximum root and shoot length were noticed from the rice plants obtained from the seed treated with $T$. harzianum strain IRRI-6 followed by rice plants obtained from the seed treated with $T$. harzianum strain IRRI-1 and
IRRI-3. The remaining strains of $T$. harzianum i.e. IRRI-4, IRRI-2, SVP-1 IRRI-5 and SVP-3 resulted in intermediate type of root and shoot length of rice plants, which were almost statistically similar to each other. Rice plants obtained from the seed treated with $\mathrm{TH}-3$ strain of $T$. harzianum resulted in minimum root and shoot length, which was lowest among all treatments.

\section{Root and shoot fresh weight}

All the strains of $T$. harzianum resulted in considerable level of increase in root and shoot biomass which is evident from the record on root and shoot fresh weight. However, the highest root and shoot biomass was recorded from the rice plants treated with T. harzianum strains IRRI-1 followed by IRRI-3 and IRRI-4.

The T. harzianum strains IRRI-6, SVP-1 and SVP-3 were found to be closely similar with regard to increasing root and shoot biomass. The strains of T. harzianum i.e. IRRI-5, IRRI2 and TH-3 were found to be least effective in enhancing the root and shoot biomass, however still better than untreated check. Similar trends of results were noticed in 42 days after seed sowing also. Thus, it can be concluded that seed treatment with $T$. harzianum in rice is able to enhance the root and shoot development.

T. harzianum have been reported to induce the growth of various crops. These responses may be due to- (i) suppression of deleterious root micro-flora including those not causing obvious disease, (ii) production of growth stimulating factors (hormones or growth factors) and/or (iii) Increased nutrient uptake through solubilization and sequestration of nutrients and/or enhanced root growth. Enhanced root development is also helpful in tolerating the biotic and abiotic stresses by the plants. 
Table.1 Effect of rice seed bio-priming with different strains of T. harzianum on root and shoot development at 21 days after sowing in the rice crop season 2012

\begin{tabular}{|c|l|l|l|l|l|}
\hline Treatments & $\begin{array}{l}\text { Strains of } \\
\text { T. harzianum }\end{array}$ & $\begin{array}{l}\text { Shoot } \\
\text { Length } \% \\
\text { increase over } \\
\text { the control }\end{array}$ & $\begin{array}{l}\text { Root length } \\
\text { \% increase } \\
\text { over the } \\
\text { control }\end{array}$ & $\begin{array}{l}\text { Shoot fresh } \\
\text { weight \% } \\
\text { increase } \\
\text { over the } \\
\text { control }\end{array}$ & $\begin{array}{l}\text { Root fresh } \\
\text { weight } \% \\
\text { increase } \\
\text { over the } \\
\text { control }\end{array}$ \\
\hline $\mathrm{T}_{1}$ & T. harzianum (IRRI-1) & 35.00 & 58.79 & 54.90 & 37.31 \\
\hline $\mathrm{T}_{2}$ & T. harzianum (IRRI-2) & 15.76 & 33.23 & 19.61 & 28.36 \\
\hline $\mathrm{T}_{3}$ & T. harzianum (IRRI-3) & 23.24 & 19.49 & 40.20 & 22.39 \\
\hline $\mathrm{T}_{4}$ & T. harzianum (IRRI-4) & 16.02 & 10.86 & 39.22 & 16.42 \\
\hline $\mathrm{T}_{5}$ & T. harzianum (IRRI-5) & 13.85 & 23.32 & 19.61 & 20.90 \\
\hline $\mathrm{T}_{6}$ & T. harzianum (IRRI-6) & 43.60 & 47.92 & 33.33 & 43.28 \\
\hline $\mathrm{T}_{7}$ & T. harzianum (TH-3) & 7.29 & 23.64 & 9.80 & 23.88 \\
\hline $\mathrm{T}_{\mathbf{8}}$ & T. harzianum (SVP-1) & 14.05 & 19.17 & 34.31 & 22.39 \\
\hline $\mathrm{T}_{9}$ & T. harzianum (SVP-3) & 11.16 & 12.78 & 33.33 & 7.46 \\
\hline $\mathrm{T}_{10}$ & Control & 0.00 & 0.00 & 0.00 & 0.00 \\
\hline & CD @ $\%$ level & $\mathbf{0 . 8 6 8}$ & $\mathbf{0 . 2 9 1}$ & $\mathbf{0 . 1 1 5}$ & $\mathbf{0 . 0 5 2}$ \\
\hline & SE(m) & $\mathbf{0 . 2 9 2}$ & $\mathbf{0 . 1 3 4}$ & $\mathbf{0 . 0 6 6}$ & $\mathbf{0 . 0 1 7}$ \\
\hline
\end{tabular}

Table.2 Effect of rice seed bio-priming with different strains of T. harzianum on root and shoot development at 21 days after sowing in the rice crop season 2013

\begin{tabular}{|c|c|c|c|c|c|}
\hline Treatments & $\begin{array}{l}\text { Strains of } \\
T . \text { harzianum }\end{array}$ & $\begin{array}{l}\text { Shoot } \\
\text { Length \% } \\
\text { increase } \\
\text { over the } \\
\text { control }\end{array}$ & $\begin{array}{l}\text { Root length } \\
\% \text { increase } \\
\text { over the } \\
\text { control }\end{array}$ & $\begin{array}{l}\text { Shoot fresh } \\
\text { weight } \% \\
\text { increase } \\
\text { over the } \\
\text { control }\end{array}$ & $\begin{array}{l}\text { Root fresh } \\
\text { weight } \% \\
\text { increase } \\
\text { over the } \\
\text { control }\end{array}$ \\
\hline $\mathbf{T}_{1}$ & T. harzianum (IRRI-1) & 28.25 & 36.16 & 36.54 & 35.38 \\
\hline $\mathbf{T}_{2}$ & T. harzianum (IRRI-2) & 16.57 & 34.28 & 35.58 & 32.31 \\
\hline $\mathbf{T}_{3}$ & T. harzianum (IRRI-3) & 21.79 & 14.47 & 26.92 & 24.62 \\
\hline $\mathbf{T}_{4}$ & T. harzianum (IRRI-4) & 13.05 & 13.52 & 26.92 & 20.00 \\
\hline $\mathbf{T}_{5}$ & T. harzianum (IRRI-5) & 10.37 & 22.01 & 16.35 & 24.62 \\
\hline $\mathrm{T}_{6}$ & T. harzianum (IRRI-6) & 27.59 & 34.59 & 31.73 & 32.31 \\
\hline$\overline{\mathbf{T}_{7}}$ & T. harzianum (TH-3) & 8.55 & 15.41 & 16.35 & 20.00 \\
\hline$\overline{T_{8}}$ & T. harzianum (SVP-1) & 9.85 & 11.63 & 16.35 & 15.38 \\
\hline$T_{9}$ & T. harzianum (SVP-3) & 8.74 & 12.58 & 26.92 & 10.77 \\
\hline $\mathbf{T}_{10}$ & Control & 0.00 & 0.00 & 0.00 & 0.00 \\
\hline \multicolumn{2}{|c|}{ CD@5\% level } & 0.968 & 0.231 & 0.125 & 0.046 \\
\hline \multicolumn{2}{|c|}{$\mathrm{SE}(\mathbf{m})$} & 0.262 & 0.114 & 0.076 & 0.017 \\
\hline
\end{tabular}


Table.3 Effect of rice seed biopriming with different strains of T. harzianum on root shoot development at 42 days after sowing in the rice crop season 2012

\begin{tabular}{|c|l|l|l|l|l|}
\hline Treatments & $\begin{array}{l}\text { Strains of } \\
\text { T. harzianum }\end{array}$ & $\begin{array}{l}\text { Shoot } \\
\text { Length \% } \\
\text { increase } \\
\text { over the } \\
\text { control }\end{array}$ & $\begin{array}{l}\text { Root length } \\
\text { \% increase } \\
\text { over the } \\
\text { control }\end{array}$ & $\begin{array}{l}\text { Shoot fresh } \\
\text { weight \% } \\
\text { increase over } \\
\text { the control }\end{array}$ & $\begin{array}{l}\text { Root fresh } \\
\text { weight \% } \\
\text { increase } \\
\text { over the } \\
\text { control }\end{array}$ \\
\hline $\mathrm{T}_{1}$ & T. harzianum (IRRI-1) & 21.77 & 92.92 & 46.24 & 78.69 \\
\hline $\mathrm{T}_{2}$ & T. harzianum (IRRI-2) & 14.27 & 59.55 & 30.97 & 58.11 \\
\hline $\mathrm{T}_{3}$ & T. harzianum (IRRI-3) & 5.37 & 58.76 & 45.26 & 25.18 \\
\hline $\mathrm{T}_{4}$ & T. harzianum (IRRI-4) & 4.13 & 46.40 & 17.67 & 24.21 \\
\hline $\mathrm{T}_{5}$ & T. harzianum (IRRI-5) & 4.30 & 34.04 & 39.26 & 43.10 \\
\hline $\mathrm{T}_{6}$ & T. harzianum (IRRI-6) & 19.54 & 71.12 & 49.40 & 72.40 \\
\hline $\mathrm{T}_{7}$ & T. harzianum (TH-3) & 1.73 & 39.55 & 21.81 & 65.13 \\
\hline $\mathrm{T}_{8}$ & T. harzianum (SVP-1) & 7.42 & 49.44 & 37.08 & 11.14 \\
\hline $\mathrm{T}_{9}$ & T. harzianum (SVP-3) & 8.09 & 28.88 & 32.06 & 11.38 \\
\hline $\mathrm{T}_{10}$ & Control & 0.00 & 0.00 & 0.00 & 0.00 \\
\hline & CD @ 5\% level & $\mathbf{1 . 1 0}$ & $\mathbf{1 . 2 4}$ & $\mathbf{1 . 1 8}$ & $\mathbf{1 . 0 9}$ \\
\hline & SE(m) & $\mathbf{0 . 7 9}$ & $\mathbf{0 . 9 7}$ & $\mathbf{0 9 7}$ & $\mathbf{0 . 7 3}$ \\
\hline
\end{tabular}

Table.4 Effect of rice seed biopriming with different strains of T. harzianum on root shoot development at 42 days after sowing in the rice crop season 2013

\begin{tabular}{|c|l|l|l|l|l|}
\hline Treatments & $\begin{array}{l}\text { Strains of } \\
\text { T. harzianum }\end{array}$ & $\begin{array}{l}\text { Shoot } \\
\text { Length } \\
\text { increase } \\
\text { over the } \\
\text { control }\end{array}$ & $\begin{array}{l}\text { Root } \\
\text { length } \\
\text { increase } \\
\text { over the } \\
\text { control }\end{array}$ & $\begin{array}{l}\text { Shoot fresh } \\
\text { weight \% } \\
\text { increase over } \\
\text { the control }\end{array}$ & $\begin{array}{l}\text { Root fresh } \\
\text { weight } \% \\
\text { increase } \\
\text { over the } \\
\text { control }\end{array}$ \\
\hline $\mathrm{T}_{1}$ & T. harzianum (IRRI-1) & 23.18 & 61.44 & 43.33 & 79.40 \\
\hline $\mathrm{T}_{2}$ & T. harzianum (IRRI-2) & 15.47 & 55.28 & 38.44 & 56.12 \\
\hline $\mathrm{T}_{3}$ & T. harzianum (IRRI-3) & 8.88 & 54.47 & 31.15 & 31.34 \\
\hline $\mathrm{T}_{4}$ & T. harzianum (IRRI-4) & 11.84 & 44.37 & 16.98 & 43.28 \\
\hline $\mathrm{T}_{5}$ & T. harzianum (IRRI-5) & 11.16 & 35.54 & 30.63 & 22.69 \\
\hline $\mathrm{T}_{6}$ & T. harzianum (IRRI-6) & 21.73 & 71.89 & 46.88 & 87.16 \\
\hline $\mathrm{T}_{7}$ & T. harzianum (TH-3) & 8.45 & 35.77 & 15.63 & 69.85 \\
\hline $\mathrm{T}_{8}$ & T. harzianum (SVP-1) & 8.47 & 42.51 & 22.60 & 22.99 \\
\hline $\mathrm{T}_{9}$ & T. harzianum (SVP-3) & 9.13 & 29.73 & 26.15 & 27.16 \\
\hline $\mathrm{T}_{10}$ & Control & 0.00 & 0.00 & 0.00 & 0.00 \\
\hline & CD @ 5\% level & $\mathbf{1 . 3 6}$ & $\mathbf{1 . 0 4}$ & $\mathbf{0 . 9 6}$ & $\mathbf{0 . 6 5}$ \\
\hline & SE(m) & $\mathbf{0 . 7 2}$ & $\mathbf{0 . 6 5}$ & $\mathbf{0 . 5 8}$ & $\mathbf{0 . 2 8}$ \\
\hline
\end{tabular}

The present study is in agreement with Shukla et al., (2015) observed that the seed biopriming with drought tolerant isolates of Trichoderma harzianum promote growth and drought tolerance in Triticum aestivum. Tomer et al., (2016) studied the suitability of de-oiled cakes 
of neem, jatropha, mahua and karanja along with cereals and millets substrates for mass multiplication of Trichoderma harzianum. These results are also in agreement with those of other workers Harcz (2002), Howell (2003), Harman et al., (2004) and Segarra et al., (2007).

It can be concluded that out of ten treatments of $T$. harzianum strains, few strains have been found to enhance the root and shoot length along with enhancing root and shoot biomass in the rice plants when these strains were applied to the rice crop through seed bio-priming. The highest root and shoot biomass was recorded from the rice plants treated with $T$. harzianum strains IRRI-1 followed by IRRI-3 and IRRI-4.

\section{Acknowledgements}

The authors are cordially grateful to Dr. U.S. Singh, Senior Scientist \& South East Asia Coordinator STRASA project IRRI, for providing special research facilities, provide funding for research and assisting me to carry out the embodied work.

\section{References}

Department of Agriculture and Cooperation (2016). Department of Agriculture and Cooperation Ministry of Agriculture, Government of India. http://agricoop. nic.in/

FAO (2016). Food and Agriculture Organization, Rome, http://faostat. fao.org/

Harcz, P. (2002). The role of Trichoderma in the rhizosphere of tomato plants. Tiszantuli Novenyvedelmi Forum, 16-17 October 2002, Debrecen, Hungary; 118124.
Harman, G. E., Petzoldt, R., Comis, A. and Chen, J. (2004) Interactions between Trichoderma harzianum strain T22 and maize inbred line Mo17 and effects of this interaction on diseases caused by Pythium ultimum and Colletotrichum graminicola. Phytopathology, 94(2): 147153.

Howell, C.R. (2003). Mechanisms employed by Trichoderma species in the biological control of plant diseases: the history and evolution of current concepts. Plant Dis. 87 4-10.

IRRI-International Rice Research Institute (1996). Standard Evaluation System for rice. 4th edn. Int. Network for Genetic Evaluation of Rice, Genetic Resource Center, Los Baños, The Philippines.

NIASM (2016). National institute of abiotic stress management. ICAR, Government of India. htpp://www.niam.res.in

Segarra, G., Casanova, E., Bellido, D., Odena, M. A., Oliveira, E. and Trillas, I. (2007). Proteome, salicylic acid, and jasmonic acid changes in cucumber plants inoculated with Trichoderma asperellum strain T34. Proteomics; 7(21): 3943-3952.

Shukla, N., Awasthi, R. P., Rawat, L. and Kumar, J. 2015. Seed biopriming with drought tolerant isolates of Trichoderma harzianum promote growth and drought tolerance in Triticum aestivum. Annals of Applied Biology, 166(2): 171-182.

Tomer, A., Singh, R. and Singh, P. 2016. Studied the suitability of de-oiled cakes of neem, jatropha, mahua and karanja along with cereals and millets substrates for mass multiplication of Trichoderma harzianum. Academy of Agriculture Journal. 1(2): 23-27.

\section{How to cite this article:}

Ranvijay Singh, Ramji Singh, U.S. Singh, Durga Prasad and Ajay Kumar. 2018. Management of Early Drought in Rice with Most Suitable Strains of Trichoderma harzianum. Int.J.Curr.Microbiol.App.Sci. 7(05): 1480-1485. doi: https://doi.org/10.20546/ijcmas.2018.705.174 